\title{
Perspectives on implementing certification on Crown forest: The case of Newfoundland and Labrador
}

\author{
by C. Fox' ${ }^{1}$, M. van Zyll de Jong ${ }^{1, *}$, B. Hearn², L. Moores ${ }^{3}$, P. Foley ${ }^{1}$ and D. Harris²
}

\begin{abstract}
This paper makes empirical and practical contributions to answering the question of how public and private forestry stakeholders can effectively interact in the management of the forestry sector, through an evaluation of government and industry perspectives on implementing forest certification on unalienated Crown lands in Newfoundland and Labrador. In order to evaluate the possibility and practicality of implementing certification, this study surveyed forestry stakeholders from the provincial forest service, pulp and paper industry and sawmill/product industry to discover their views on this topic and determine whether they share complementary forest certification goals. Overall, the majority of respondents agreed that certification should be pursued and favoured a joint government-industry approach to leading and financing this initiative.
\end{abstract}

Keywords: forest certification, government, industry perspectives

\section{RÉSUMÉ}

Cet article tente d'apporter une réponse empirique et pratique à la question de savoir comment les intervenants de la forêt publique et de la forêt privée peuvent interagir efficacement en matière d’aménagement forestier à partir d'une évaluation des perspectives gouvernementale et de l'industrie sur l'implantation de la certification forestière sur les terres publiques non aliénées de Terre-Neuve et du Labrador. De façon à évaluer s'il était possible et faisable d'implanter la certification, on a effectué un sondage auprès des intervenants du service forestier provincial, de l'industrie des pâtes et papiers, du sciage et des produits du bois afin de connaitre leurs opinions sur ce sujet et de déterminer s'ils ont en commun dautres objectifs liés à la certification forestière. De façon générale, la majorité des répondants sont favorables à la certification et préféreraient une approche mixte entre le gouvernement et l'industrie pour la mise en oeuvre et le financement de ce projet.

Mots clés : certification forestière, gouvernement, points de vue de l'industrie

\section{Introduction}

Over the last two decades, third-party certification to environmental standards has become an important international tool for verifying and communicating the sustainability of forestry management practices and commercial forest products. Certification is one tool to demonstrate consumer confidence that a forest product has been produced from a forest that meets a third-party sustainability standard. Certification has evolved to become a requirement to maintain and expand market access as well as to provide independent verification of environmental sustainability.

By attempting to derive policy-making authority from market transactions instead of traditional forms of state power, forest certification schemes can be characterized as a form of non-state market-driven (NSMD) governance that focuses on manipulating the market's supply chain in order to incentivize companies to comply with environmentally and socially responsible management practices (Cashore 2002). While the rise of certification in forestry and in other sectors has raised concerns about a perceived transfer of power away from sovereign governments, studies have shown that certification does not necessarily supplant or conflict with the role of government in the policy and decision-making sphere, but more often acts as an interactive complement to existing regulatory authorities and structures (Cashore 2002, Rametsteiner 2002, Gulbrandsen 2004, Wood 2009). Expanding on this conclusion, Lister (2009) argues that the concept of a "coregulatory forest governance system" best describes the role of certification in forestry governance, given that implementation hinges on policy alignment and regulatory compliance, and governments play a key role in the sovereign capacity to oversee, facilitate, legitimate, and even enforce certification standards. Cashore et al. (2004) list a number of ways in which governments can actively participate in and shape certification systems: (1) enforce existing rules and policies extraneous to certification; (2) exert influence on certification systems' policy-making processes; (3) implement procurement policies to similarly influence the market supply chain;

\footnotetext{
${ }^{1}$ Environmental Policy Institute, Grenfell Campus, Memorial University, Corner Brook, NL ${ }^{\star}$ corresponding author: michaelv@grenfell.mun.ca ${ }^{2}$ Canadian Forest Service, Natural Resources Canada, Corner Brook, NL

${ }^{3}$ Private Consultant, Corner Brook, NL
} 
(4) approve or facilitate certification on government-owned lands; (5) promote certification by providing administrative or financial resources to groups pursuing certification; and, (6) develop a national certification system or participate in the establishment of regional standards for existing schemes. While significant research has been conducted on certification, more is needed to disentangle the complex varieties of state/non-state interactions (Auld et al. 2008). The key challenge, according to Eberlein et al. (2013), is to understand the implications of these interactions for regulatory capacity and performance, and ultimately for social and environmental impact.

Canada's forest industry is at the forefront of certifying forestlands. Emerging from a multi-year cyclical decline, the forest sector is focused on operationalizing a transformative strategy of innovation and market development (NRCan 2013). As of 2014, 161 million hectares of forestlands were certified to a recognized standard in Canada, giving the country the distinction of having the largest area (approximately $43 \%$ ) of third-party independently certified forests in the world (NRCan 2016). In the province of Newfoundland and Labrador (NL), Corner Brook Pulp and Paper Limited (CBPPL), which owns and operates the remaining pulp and paper mill in the province, has met several forest certification standards on its licenced forest lands over the past decade: the ISO 14001 Environmental Management System (EMS) Standard, in July 2001; the CAN/CSA Z809 Sustainable Forest Management System (SFM) Standard, in August 2004; and most recently, the FSC National Boreal Standard, in July 2012 (CBPPL 2001, FPAC 2012). At the time of this study, the company's licenced lands were the only forestlands in the province certified to third-party forest management standard.

The province has 8.8 million hectares of productive forested land (DNR 2011a), and forest management and planning falls under the jurisdiction of the Forestry and Agrifoods Agency. As early as 2001, and in parallel to industry sector advancements in certification, the province began evaluating the possibility of implementing an EMS on unalienated Crown forests, through the ISO 14001 EMS Standard. Although it is not unique for provinces in Canada to have more public than privately owned land, the Crown owns more land in NL (over 95\%) than in any other province (Luckert et al. 2011). Saunders and Duinker (2002) conducted a gap analysis in order to identify potential barriers facing the Newfoundland Forest Service should it attempt to implement the ISO 14001 EMS Standard. The authors identified a series of partial and keystone barriers but ultimately concluded that "no potential barriers pose insurmountable hurdles, and that ISO 14001 registration should proceed expeditiously". Limited research on certification of NL unalienated Crown lands has been undertaken since, despite significant changes to the forest industry in the past decade and the increasing global extent of, and market demands for, certification.

Four factors suggest that it would be beneficial to revisit the interest in implementing certification on unalienated Crown land in NL. First, although no potential barriers were deemed "insurmountable hurdles" at the time of the Saunders and Duinker (2002) study, the fact that neither an EMS nor a SFM certification standard had been implemented on unalienated Crown lands at the time of this study suggests that barriers do indeed exist. Second, Saunders and Duinker (2002) focused solely on the ISO 14001 EMS Standard; context-specific information applicable to additional standards is absent. Third, major changes have occurred within the forest sector and the broader economy in the province, and therefore views on certification may have also changed over the past decade. Finally, the provincial Department of Natural Resources' 2011-2014 Strategic Plan (DNR 2011b) stated that the Forestry and Agrifoods Agency should develop an EMS for certification of Crown forestry operations as a priority, thus bringing the certification issue back onto the public policy agenda and allowing for a renewed look at the feasibility of implementing this system. In light of the province's renewed commitment to achieving certification, an updated study is required in order to take into account the perspectives of government and the forest industry sector on this topic.

The purpose of this study, through a survey of forestry professionals in the provincial government and pulp and paper and sawmill/product industry, is to determine attitudes toward certification on unalienated Crown lands and to uncover perspectives on the roles that government and industry should play in the certification process. Determining government and industry opinions on the issue of forest certification is important for a variety of reasons. Firstly, the involvement of these players may help to create policies and projects that are more efficient, effective, and mutually acceptable to all parties. In addition, discussions relating to SFM planning and implementation should similarly seek to foster greater stakeholder engagement. According to Lister (2009), certification authority can be viewed as a "virtuous cycle" comprised of stakeholder engagement and learning, cooperation and trust, collaborative decision making regarding SFM, and therefore legitimate private authority. Lister (2009) further notes that since non-state processes such as certification derive their legitimacy from market and public acceptance, ensuring transparency and inclusiveness are necessary precursors to the long-term viability and success of these initiatives. Finally, all certification standards insist on some level of collaboration and participation from forestry stakeholders as a requirement.

This paper will examine three key questions: (1) What are the perceptions of forestry professionals concerning the implementation of certification systems on unalienated Crown lands in NL; do they support implementation and why? (2) What do they think are the main challenges and barriers to implementing certification? (3) Who do they think should be responsible for leading and financing certification, and why?

\section{Methods}

The study utilized semi-structured surveys to assess and compare opinions of stakeholders on the topic of implementing forest certification on unalienated NL Crown lands. The survey was broadly divided into four sections: background information on respondents and their views on certification; questions on possible barriers to achieving certification; questions about responsibility for facilitating certification; and, future directions for the province. Respondents from the provincial government, the pulp and paper industry, and sawmill/product industry were invited to participate. Although Crown 
forests are a public resource, and therefore many individuals and organizations may be defined as stakeholders, this survey was inclusive of only the aforementioned groups. As its purpose was to uncover the opinions of individuals employed in the NL forest industry and thus directly affected by a certification decision, individuals in these sectors were surveyed to provide the responses for future decision-making on this issue. Therefore, a purposive sample was justified in the interest of soliciting targeted opinions. A brainstorming session with individuals from the Newfoundland Forest Service (NFS), the Canadian Forest Service (CFS), and the private sector identified lists of possible respondents from each sector. Within the NFS, a stratified sample of respondents was chosen to capture a diverse range of opinions, ranging from top management personnel to technical officers operating in the field. A breakdown of the sectors selected for participation, as well as the specific employment categories within government, is provided (Table 1). For the pulp and paper industry, respondents were chosen based on their understanding of certification or their direct involvement in CBPPL's certification process. For the sawmill industry, a central contact list of the major companies was provided by the provincial government. In total, 61 individuals were asked to participate in the study. Due to the relatively small size of the industrial forest sector in the province, employees of the provincial government dominated the sample. Surveys were designed using Dillman's Mail and Internet Surveys: The Tailored Design Method (2007) and administered through a web survey company (SurveyMonkey). Due to geographic distribution and the need for a wide sample across government and industry, a virtual survey mechanism was chosen. The use of a virtual survey also allowed for flexibility in giving the participants a choice of when to complete the survey as well as offering the investigators instantaneous results. A survey pre-test was completed in early May 2013 by a small group from the NFS

Table 1. Profile of potential survey respondents by (A) sector and (B) employment descriptor, for provincial government employees

\begin{tabular}{lc} 
A. Sector & \# of individuals sent survey \\
\hline Provincial Government & 41 \\
Pulp and Paper Industry & 11 \\
Sawmill and Product Industry & 9 \\
\hline Total & $\mathbf{6 1}$ \\
\hline B.Provincial government & \\
employment descriptor & \# of individuals sent survey \\
\hline Executive/Director & 4 \\
Supervisor & 9 \\
Ecosystem Manager & 1 \\
District Manager & 8 \\
Regional Planners, Ecologists, & 10 \\
$\quad$ Compliance Officer & 9 \\
Conservation Officer (IV) & $\mathbf{4 1}$ \\
\hline Total & \\
\hline
\end{tabular}

and the CFS. Feedback from the pre-test was collected and incorporated to improve the clarity and design of the survey. The survey was emailed to participants on May 13, 2013 and responses were collected to June 21, 2013. Two reminder emails were sent to all participants to encourage response rates. Because the survey was administered and completed online, the study was subject to a self-reporting bias and the reliability and validity of responses cannot be verified. Similarly, because the researcher was not present during the completion of the survey, respondents may have been unclear about survey requirements or contents. However, this limitation was diminished due to the inclusion of a survey pre-test.

\section{Results}

\section{General respondent profile}

A total of 31 surveys were completed, providing a response rate of $50 \%$ with a breakdown by sector as follows: 24 respondents (77\%) from the provincial government, four (13\%) from the pulp \& paper industry and three (10\%) from the sawmill industry (Table 1). Across all sectors, the majority of respondents $(68 \%)$ had worked in the forest sector for over twenty years. No respondents had worked in the forest sector for less than one year (Table 2).

\section{Perceptions concerning the implementation of certification}

Ninety percent of respondents agreed or strongly agreed that they were aware of the province's goal to certify unalienated Crown forests, and a further $90 \%$ agreed or strongly agreed that they were familiar with forest certification standards. A smaller majority $(74 \%)$ indicated their agreement with the statement that "unalienated Crown forests in NL are currently managed in a sustainable way", with $19 \%$ neither agreeing nor disagreeing (Table 3A).

Reasons for and against achieving provincial forest certification: Slightly more than half of the respondents (55\%) agreed that forest certification should be implemented on NL unalienated Crown lands (Table 3B). These respondents were asked to indicate their agreement of a list of possible reasons for achieving forest certification (Table 4). In order of importance, these included: improving public image; improving sustainability in forest practices; securing market access; and, improving market competitiveness. $36 \%$ of respondents were unsure as to whether forest certification should be implemented on unalienated Crown lands, and 7\% of respondents

Table 2. Actual respondents' profiles by (A) sector affiliation and $(B)$ years of relevant experience

\begin{tabular}{lc} 
A. Sector & n \\
\hline Provincial Government & 24 \\
Pulp and Paper Industry & 4 \\
Sawmill/Product Industry & 3 \\
\hline B. Experience & \\
\hline Less than 1 & 0 \\
$1-5$ & 2 \\
$6-19$ & 8 \\
$20+$ & 21 \\
\hline
\end{tabular}


Table 3. Responses to questions concerning: (A) awareness of forest operations and certification on unalienated Newfoundland and Labrador Crown lands ( 1 = strongly disagree; 2 = disagree; 3 = neutral; 4 = agree; 5 = strongly agree) and (B) opinions on implementation of forest certification on Newfoundland and Labrador Crown lands [\% response]

\section{A. Please indicate your level of agreement with the following statements:}

I am aware of the province's goal to certify its Crown forests

I am familiar with forest certification standards

Crown forests in Newfoundland and Labrador are currently managed in a sustainable way

B. Forest certification should be implemented on Newfoundland and Labrador Crown lands:

Rating Scale

\begin{tabular}{llllllll}
\hline 1 & 2 & 3 & 4 & 5 & Mean & $\mathrm{n}$ \\
\hline
\end{tabular}

$\begin{array}{ccccccc}1 & 0 & 2 & 9 & 19 & 4.5 & 31 \\ 1 & 0 & 2 & 16 & 12 & 4.2 & 31 \\ 1 & 1 & 6 & 13 & 10 & 3.9 & 31\end{array}$

\begin{tabular}{ccc} 
Response & $\%$ & $\mathbf{n}$ \\
\hline Yes & 54.8 & 17 \\
No & 6.5 & 2 \\
Unsure & 35.5 & 11 \\
No Opinion & 3.2 & 1 \\
\hline
\end{tabular}

Table 4. Reasons for and against implementation of forest certification on unalienated Newfoundland and Labrador Crown lands, including implications for business opportunities

\begin{tabular}{rrr}
\hline$\%$ & Count \\
\hline
\end{tabular}

Possible reasons for deciding not to achieve forest certification $(n=2)$

- Financial cost

$100.0 \quad 2$

- Unlikely to enable price premiums

$100.0 \quad 2$

- Unnecessary for current business opportunities 100.0

- Loss of control over forest management

50.0

0.0

$0.0 \quad 0$

- Other (please specify)

Possible reasons for achieving forest certification $(n=18)$

- Securing market access $83.3 \quad 15$

- Improving market competitiveness

77.8

94.4

100.0

- Improving public image

- Streamlining management operations

66.7

27.8

- Obtaining price premiums for products

22.2

Has the lack of certification on Crown forests posed a problem for you or your organization in terms of business opportunities?

- Yes

$10.3 \quad 3$

- No

44.8

- Unsure

24.1

- Not Applicable

20.7

were opposed. When prompted to list the reasons behind this view, the respondents noted financial cost, the unlikeliness of certification to enable price premiums, and their belief that certification is unnecessary in the context of maintaining current business opportunities.
Certification and business opportunities: All respondents were asked to indicate whether the province's uncertified timber was experiencing difficulty entering markets, with the recognition that this question would apply more to individuals working in private industry than those employed by the government. Only 10\% of those surveyed indicated that the lack of certification had posed a problem in accessing business opportunities (Table 4). A respondent noted that because CBPPL is currently using the FSC Mixed Sources logo for its forest products, it is still able to use uncertified Crown wood. This respondent further stated that it is not uncommon for businesses to use the mixed wood designation for forest products, and CBPPL's inability to use a FSC 100\% logo has thus far not had a negative impact on accessing market opportunities.

\section{Identification of barriers to implement certification}

Respondents were asked to rate a list of challenges to forest certification that had been uncovered in previous studies (Table 5). Overall they did not uniformly identify any one potential barrier as being especially problematic, and responses were largely divided between the categories of 'not a barrier', 'slight barrier', and 'major barrier'. In keeping with the approach taken by Saunders and Duinker (2002), it was decided that in order for a challenge to be deemed a major barrier, at least half of the respondents must have categorized it as such. Using this methodology, no major barriers were uncovered. Conversely, only one issue (poor relationship between government and industry) was identified by more than half of the respondents as 'not a barrier'. Therefore, a poor relationship between these parties was not felt by the majority of respondents to be a barrier to implementing certification on unalienated Crown forests.

Main barriers: Although none of the potential barriers met the required criteria to be labelled a major barrier (i.e., identified by more than $50 \%$ of respondents), three issues 
Table 5. Potential challenges to achieving forest certification: relevance to unalienated Newfoundland and Labrador Crown lands (Rating: 1 = not a barrier; 2 = slight barrier; 3 = major barrier; mean score and count)

\begin{tabular}{|c|c|c|c|c|c|c|}
\hline Options & 1 & 2 & 3 & Unsure & Mean & $\mathbf{n}$ \\
\hline - Direct and indirect financial costs of certification & 2 & 12 & 13 & 2 & 2.41 & 29 \\
\hline - Availability of staff time to commit to certification & 4 & 9 & 13 & 3 & 2.35 & 29 \\
\hline - Documentation and reporting requirements of certification & 6 & 13 & 8 & 2 & 2.07 & 29 \\
\hline - Unclear division of responsibility for certification & 3 & 12 & 6 & 8 & 2.14 & 29 \\
\hline - Conflicting governmental and certification priorities & 3 & 15 & 6 & 5 & 2.13 & 29 \\
\hline - Unrealistic management expectations about ability to implement certification & 7 & 11 & 5 & 6 & 1.91 & 29 \\
\hline - Gaps between existing legislation and certification requirements & 8 & 10 & 4 & 7 & 1.82 & 29 \\
\hline - Difficulty in communicating across multiple forest management districts & 10 & 12 & 5 & 2 & 1.81 & 29 \\
\hline - Management inconsistencies across multiple forest districts & 8 & 14 & 6 & 1 & 1.93 & 29 \\
\hline - Poor relationship between industry and government & 17 & 6 & 2 & 4 & 1.40 & 29 \\
\hline - Changing government priorities & 5 & 12 & 9 & 3 & 2.15 & 29 \\
\hline - Political interference in forest management & 4 & 8 & 13 & 4 & 2.36 & 29 \\
\hline
\end{tabular}

were listed as major barriers by $45 \%$ of respondents: (1) direct and indirect costs of certification; (2) availability of staff time to commit to certification; and, (3) political interference in forest management (Table 5).

Forest certification necessitates significant financial inputs, and respondents were well aware of these costs. In the survey, individuals were given an opportunity to provide additional comments on barriers to certification, and many of those who responded elaborated on the financial aspects. Respondents referred specifically to the many small contractors operating on Crown land, and highlighted the difficulties they expected this group would face in absorbing the cost of certification. These respondents believed that any potential benefits associated with certification would be largely accrued by large industry, while small operators would undergo significant financial difficulties to bring their operations up to required standards.

Three respondents commented on the difficulty of monitoring and ensuring compliance to the requirements of a certification standard on a province-wide basis. One noted that non-compliance issues would have to be dealt with through legal avenues or by withholding/cancelling permits, likely resulting in political interference "which will be difficult to defend to third-party auditors". This statement was also echoed by another respondent who noted that political interference would likely "complicate the certification process".

Non-barriers: Seventeen respondents indicated that a poor relationship between industry and government would not pose a barrier to achieving certification. This response generated the greatest source of agreement in this section. Correspondingly, respondents did not collectively find that the challenges inherent in communicating across multiple forest management districts would act as a key barrier, as this category received the second lowest rating (Table 5).

\section{Perceptions on government and industry capacities for imple- menting certification}

Comparison of government and industry capacities: Respondents were provided with a list of issues that could hinder the uptake of certification, and were asked to compare the ability of industry and government to successfully address them (Table 6). The industry focus here is on forest contractors with Crown cutting permits, as CBPPL was first certified to the ISO 14001 EMS Standard in 2001, and is also certified to the CAN/CSA Z809 Sustainable Forest Management System (SFM) Standard and the FSC National Boreal Standard. Given that the literature on certification asks for further research on the degree to which governments have been and should be involved in this process, the purpose of these questions was to cause respondents to think about the relative capacities of both government and industry to handle the requirements of certification. Therefore, respondents would be better equipped to answer subsequent questions on responsibility for certification.

The government was more consistently ranked ahead of industry; however, the margins between the two groups were often quite small. When the collective rankings for each group were averaged, the government earned an average of 3.03 (neutral) and industry an average of 2.77 (weak). These findings suggest that respondents are not particularly confident in the ability of either party to manage the requirements of certification.

Both groups garnered almost identical overall ratings in the following categories: willingness of upper management to accept and commit to certification; willingness of employees to accept and commit to certification; and, ability to maintain commitment to certification despite business or government downsizing. The greatest discrepancy between the two groups was evidenced in the question on ability to finance certification, with the government earning a higher rating. This response is not surprising given that a number of respondents had previously articulated that small operators would likely face financial difficulties in certifying their operations. Although the comparative questions did not uncover striking differences in capabilities between the two groups, they did provide an interesting comparison to the barriers rated in the previous section. As many respondents identified employees' already filled workdays as problematic for achieving certification, it is not surprising that government and industry collectively received their lowest scores on their ability to manage a heavier workload and complete the substantial paperwork and documentation required for certification. 
Table 6. Requirements for achieving forest certification on unalienated Newfoundland and Labrador Crown lands: Comparison of government and industry capacity (Ranking: 1 = very weak; 2 = weak; 3 = neutral; 4 = strong; 5 = very strong; mean and count)

\begin{tabular}{|c|c|c|c|c|c|c|c|c|}
\hline & 1 & 2 & 3 & 4 & 5 & N/A & Mean & $\mathbf{n}$ \\
\hline \multicolumn{9}{|c|}{ Ability to finance certification } \\
\hline Government & 1 & 5 & 10 & 5 & 5 & 3 & 3.31 & 29 \\
\hline Industry & 3 & 13 & 4 & 5 & 1 & 3 & 2.54 & 29 \\
\hline \multicolumn{9}{|c|}{ Ability of staff to handle increased workloads } \\
\hline Government & 3 & 8 & 9 & 7 & 1 & 1 & 2.82 & 29 \\
\hline Industry & 5 & 10 & 6 & 6 & 0 & 2 & 2.48 & 29 \\
\hline \multicolumn{9}{|c|}{ Ability of staff to manage increased paperwork and documentation requirements } \\
\hline Government & 2 & 12 & 6 & 7 & 1 & 1 & 2.75 & 29 \\
\hline Industry & 6 & 10 & 6 & 3 & 1 & 2 & 2.35 & 28 \\
\hline \multicolumn{9}{|c|}{ Willingness of upper management to accept and commit to certification } \\
\hline Government & 1 & 4 & 14 & 6 & 2 & 1 & 3.15 & 28 \\
\hline Industry & 1 & 5 & 9 & 9 & 1 & 2 & 3.16 & 27 \\
\hline \multicolumn{9}{|c|}{ Willingness of employees to accept and commit to certification } \\
\hline Government & 2 & 7 & 14 & 4 & 1 & 1 & 2.82 & 29 \\
\hline Industry & 2 & 8 & 10 & 6 & 1 & 2 & 2.85 & 29 \\
\hline \multicolumn{9}{|c|}{ Ability to maintain commitment to certification despite business or government downsizing } \\
\hline Government & 1 & 10 & 11 & 4 & 0 & 2 & 2.69 & 28 \\
\hline Industry & 3 & 9 & 7 & 7 & 0 & 2 & 2.69 & 28 \\
\hline \multicolumn{9}{|c|}{ Ability to monitor and enforce certification requirements } \\
\hline Government & 1 & 9 & 10 & 5 & 3 & 1 & 3.00 & 29 \\
\hline Industry & 4 & 6 & 8 & 7 & 1 & 2 & 2.81 & 28 \\
\hline \multicolumn{9}{|c|}{ Ability to fulfill training requirements } \\
\hline Government & 0 & 5 & 7 & 11 & 3 & 1 & 3.46 & 27 \\
\hline Industry & 2 & 5 & 9 & 7 & 2 & 2 & 3.08 & 27 \\
\hline \multicolumn{9}{|c|}{ Ability to implement emergency preparedness and response measures } \\
\hline Government & 0 & 6 & 8 & 9 & 3 & 2 & 3.35 & 28 \\
\hline Industry & 1 & 7 & 9 & 8 & 1 & 2 & 3.04 & 28 \\
\hline
\end{tabular}

However, despite the fact that the direct and indirect costs of certification were identified as one of the greatest barriers, individuals did not seem particularly concerned about the government's ability to fund this initiative.

Additional strengths and weaknesses of government and industry: Respondents were given the opportunity to list additional strengths and weaknesses of government and industry for implementing certification. For government, overall responses expressed confidence in staff dedication and skill level. Other relevant strengths mentioned included the government's willingness to work with industry and utilize their expertise, and the government's emphasis on public participation in its Five-Year Forest Management Plans. In terms of weaknesses, the most common theme was low confidence that the government would prioritize certification. However, these open-ended responses conflict with ratings in the previous section: when asked to rate the willingness of upper management to accept and commit to certification, respondents did not attribute low ratings to either party. Another weakness noted was the organizational challenges that government would face in catering to the needs of many different players operating in one area, with one respondent likening govern- ment's role to that of a custodian who must manage a wide diversity of experience and education distributed over an extremely large land base.

Although it cannot be described as a direct strength, for industry, incentives for certification (in terms of market access and potential financial gain), were the most important drivers for pursuing this initiative. This view among some respondents conflicts with those who foresaw a financial burden particularly for small operators, but as noted by one individual, "Industry (small- to mid-sized companies) has the most to gain from certification, so once they realize the benefits/need, they may be its biggest advocates". Other responses referred to the skilled and capable industry staff in the province. Two respondents noted that the organizational structure of a private business is especially conducive to achieving certification. In particular, industry is able to receive the financial return from certification directly, and has a greater ability to deal with non-compliance through disincentives, penalties, disciplinary action and dismissal. When asked to list weaknesses of industry that would impact the achievement of certification, a diversity of responses was provided. Several individuals again expressed concern regarding 
industry's ability to manage the costs associated with certification, noting in particular the challenges faced by small operators. Other responses identified how industry is heavily reliant on market conditions, which were described as poor, uncertain, and unstable. The geographical dispersion of the forest industry over a large land base was also identified as a possible area of concern, with individuals specifically characterizing the industry as fragmented and divided into silos.

Responsibility for leading certification: Respondents were asked to indicate which sector or organization they believed would be best equipped to lead the implementation of forest certification on unalienated Crown lands (Table 7). Given that government and industry were closely matched in rankings in the previous block of questions, it is not surprising that a partnership was identified by the majority (55\%) as the ideal leadership option. However, the government on its own was ranked as a close second, garnering $41 \%$ of the responses. As stated by one of these respondents; "If not done by Government, it will not happen on Crown land".

Responsibility for financing certification: In a follow-up question asking which sector or organization they believed should be responsible for financing the implementation of certification, the majority of respondents (60\%) again selected the joint partnership of government and industry (Table 7). Following concerns about the costs associated with certification, this method of cost-sharing may help lessen the financial burden certification places on both parties. Although the government once again received the second highest number of votes, the margin between both options was greater than in the previous question, as here twice as many respondents chose the joint team of industry and government over government on its own.

Optimal certification standard: When asked to indicate which of the forest certification standards recognized in Canada would be best suited to certifying provincial unalienated Crown lands, $33 \%$ of respondents were either unsure or had no opinion. Preference for the FSC Boreal Standard garnered the second highest number of responses (27\%), followed by the ISO 14001 EMS Standard (23\%). 17\% of respondents selected CSA Z809 as the optimal standard (Table 7).

As the provincial Forestry and Agrifoods Agency has already stated its goal to implement an EMS, respondents may have been inclined to rank ISO 14001 Standard as a top choice. In a subsequent open-ended comments box, five respondents independently stated that implementing an EMS standard such as ISO 14001 would provide an excellent introduction to certification for the province. Three of these respondents noted that an EMS can act as an excellent base for companies at the beginning of a certification process, mentioning that CBPPL also started with the ISO 14001 EMS Standard. In particular, one individual stated, "ISO certification is probably a good first step for government. ISO will bring consistency to forest management practices, monitoring, and enforcement across the Island. That consistency will bring about improvements that will be necessary as everyone moves to the much more complicated FSC processes." No respondents chose the SFI standard, which is interesting given that this standard is the most prevalent in Canada (FPAC 2012). However, the fact that CBPPL has not pursued SFI certification for its operations has likely contributed to the lower overall profile of this standard in the province.
Table 7. Response to questions on leadership for implementation and financing of forest certification on unalienated Newfoundland and Labrador Crown lands, and preferred certification standard

$\%$

n

Please indicate who you think should be responsible for leading the implementation of forest certification on Newfoundland and

Labrador Crown lands:

- Provincial Government $\quad 41.4 \quad 12$

- Private Industry $\quad 3.4 \quad 1$

- Provincial Government and Private Industry $\quad 55.2 \quad 16$

- Non-Governmental Organizations $\quad 0.0 \quad 0$

- Other (please specify)

$0.0 \quad 0$

Please indicate who you think should be responsible for financing the implementation of forest certification on Newfoundland and

Labrador Crown lands:

- Provincial Government $30.0 \quad 9$

- Private Industry

$10.0 \quad 3$

- Provincial Government and Private Industry $\quad 60.0 \quad 18$

- Non-Governmental Organizations

- Other (please specify)

$0.0 \quad 0$

$0.0 \quad 0$

Below is a list of the certification standards currently recognized in Canada Please indicate which of the following standards you believe to be BEST suited to certifying Crown forests in Newfoundland and Labrador:

- ISO 14001 EMS Standard

- CSA Z809-08

23.3

- FSC (Boreal Standard)

16.7

- SFI 2010-2014 Standard

26.7

- Unsure / No Opinion

0.0

33.3

7
5
8
0
10

\section{Discussion}

The specific goal of this study was to determine how the topic of certifying unalienated NL Crown forests is viewed and approached by government and industry stakeholders. The majority of respondents stated that Crown lands in NL should be certified, with all of these respondents citing an improved public image as a major benefit of the process. Improving sustainability in forest practices was listed as the second most common motivator. Although the majority of respondents (55\%) were in favour of pursuing certification, a substantial minority (36\%) were either unsure or had no opinion. However, this degree of uncertainty did not appear to be a result of unfamiliarity with certification standards, but may be related to the prevailing concerns about the financial costs expressed throughout the study. In particular, the relatively small size of individual operators in the sawmill and product industry and the financial burden these operators would likely face in implementing certification were both repeatedly mentioned as areas of concern.

Although this study expanded upon some of the findings by Saunders and Duinker (2002), it was not designed to provide a direct comparison. However, it is interesting to note that some of the challenges to implementing an EMS that were deemed partial barriers in 2002 were again labelled as 
such in the context of implementing an EMS or SFM standard on unalienated Crown lands in NL. Saunders and Duinker (2002) found that the following were 'partial barriers' to implementing certification: availability of staff time; availability of monetary resources; communication and consistency between forest districts and divisions; management changes; abiding by legislation; and, ensuring emergency preparedness and response measures. In addition, political interference and the failure to obtain upper-management commitment were identified as partial barriers that could influence other barriers. Similarly, the present study did not uncover any major barriers, but identified the following three issues as the greatest barriers facing the implementation of certification on unalienated Crown lands in the province: direct and indirect costs of certification; availability of staff time to commit to certification; and, political interference in certification. As stated by Saunders and Duinker (2002), political interference is a barrier that has the potential to influence other barriers. Noting the absence of this barrier in previous literature on certification, these authors defined political interference as any situation when the public uses politicians as middlemen capable of leveraging beneficial decisions from department employees in exchange for a better chance for votes. They noted that political interference is especially prevalent in Newfoundland, where political leaders are prone to prioritize issues of social and economic importance in a province largely dependent on seasonal and subsistence-based industries. Furthermore, the fact that many citizens in NL are uniquely afforded great accessibility and proximity to legislators means that it can be difficult to ensure independence in political decisions (Saunders and Duinker 2002).

The majority of respondents indicated that the relationship between industry and government does not pose a barrier to achieving certification. Furthermore, the majority of respondents were in favour of government and industry sharing responsibility for both leading and financing certification. This preference for a joint approach to certification may stem from their belief that both parties share similar abilities. When asked to compare the capabilities of government and industry on a series of issues relevant to achieving certification, no striking differences between the two groups were found. However, the average ratings for both groups were not particularly high. These findings suggest that any reservations about certification may stem from a lack of confidence in the collective abilities of both groups.

Given the situation in Canada wherein private industry operates on publicly-owned land, these findings are particularly important and have the potential to impact many other facets of the certification process. In particular, the close collaboration between industry and government partners has been a key factor in facilitating certification uptake in several provinces. According to Lister (2009), in Ontario and New Brunswick, where forest certification was mandated for companies operating on Crown land, government worked closely with industry partners and sustained a productive dialogue to keep abreast of challenges and needs. New Brunswick's decision to certify its Crown forests was initiated by the forest industry, and government and industry jointly commissioned a consulting firm to assess stewardship and management on Crown forests before beginning the implementation process. A close alignment of priorities between government and industry was also important for the uptake of certification on British Columbia Crown lands, with Lister (2009) noting that fundamentally certification succeeded in this province because both the forest industry and the government faced the same challenge. Therefore, the fact that the majority of both government and industry respondents are not only in favour of certification on unalienated Crown lands in NL, but also refute the existence of a poor relationship between both parties, suggests that two key precursors to implementing certification have already been met.

For those respondents not in favour of a joint approach, the second most popular choice for leading implementation and financing of certification was for the government to move forward on its own. However, more respondents were in favour of the provincial government leading certification on its own than financing it solely. This response is not surprising given the respondents' preoccupation with the financial burden of certification.

This study suggests that the province's goal to implement an EMS on Crown lands is largely supported by government and industry stakeholders, and many individuals are keen for the province to pursue certification to one of the SFM standards. It is important for the province to appropriately prioritize this initiative, as previous studies that have advocated for certification have not always been able to mobilize major changes on the ground. In keeping with the provincial Department of Natural Resources' 2011-2014 Strategic Plan (DNR 2011b), NL should proceed with the necessary steps to support a more systematic and publically engaged evaluation of the barriers, costs, benefits, and opportunities to begin implementing an EMS standard on unalienated Crown lands. As noted by several respondents, this process should help to bring consistency to forest management processes and will serve as a good base should the province decide to pursue a SFM standard in the future. NL should also rely on the expertise of CBPPL as it embarks on this implementation process, as the mill has achieved one EMS and two SFM standards over the past ten years and thus is familiar with their requirements in the context of the province. Stakeholders will likely be receptive to working closely with CBPPL, as respondents favoured pursuing a certification standard already achieved by the mill.

Although government employees working in Labrador were surveyed, this study did not account for the economic and political differences within the province between the island portion of Newfoundland and the mainland portion of Labrador. More research is needed to distinguish between the circumstances of these individuals. While Labrador currently does not carry out any forest harvesting operations, it has in the past and may again in the future. More research is also needed to evaluate the costs and benefits from a management perspective. Concerns remain amongst industry and government about financial costs and human resource demands of certification in the short-run. As many of these reservations pertain to the anticipated financial burden likely to be faced by small operators, any future certification plan must clearly outline the measures that will be taken to ensure that these operators remain viable. Respondents appear to be receptive to the idea of co-funding certification, but the logistics behind any cost-sharing plan will require substantial further discussion. In the long-run, there is a possibility that forest certifica- 
tion could complement or even reduce some areas of government involvement in forest management. Currently, the province's Five-Year Operating Plans are subject to an environmental assessment before approval. If Crown forests achieve independent certification, this designation may prove sufficient to indicate sustainability, and could therefore supplant the environmental assessment process. Certification may also provide other, currently unknown opportunities for streamlining management procedures that could deliver cost and timesaving advantages.

\section{Conclusion}

Certification has emerged as a significant concept in managing forest resources. Citizens, buyers and markets desire confidence in forests being sustainably managed beyond legislated mandates. Certification is one method to seek social acceptance of management activities which are demonstrated through independent standards and third party audits. The literature documents the benefits to resource managers having secured a social licence to conduct their business. Provincial governments are in a unique situation where they are typically the primary owner of the country's forest resources. However, much of the timber resource has been allocated to forest companies through various forms of land and timber tenures. In the province of NL, the government has a direct management responsibility for two thirds of the forest resource on the Island and 100\% of Labrador. Therefore, the concept of the government seeking to meet certification standards is similar to those of industry. While governments are elected every four years, the commitment to forest sustainability and public confidence in management of the provincial forest resource will continue to be a major component of any elected government.

\section{Author's Note}

The Forestry and Agrifoods Agency, Forestry Services Branch became registered to the ISO 14001:2004 Standard on December 17, 2015. Components of the certification standard include forest access for road construction maintenance, harvesting operations (including domestic harvest), silviculture operations and the forest protection program (insects and disease), within Forest Management Districts 1-22. The Environmental Management System is audited annually to ensure continued compliance with the standard (Department of Forestry, Fisheries and Agrifoods, 2016).

\section{Acknowledgements}

We would like to thank the Environmental Policy Institute of Memorial University, the Centre for Forest Science and Innovation (CFSI) of the Department of Natural Resources, and the Institute of Biodiversity, Ecosystems Science and Sustainability (IBES) of the Department of Environment and Conservation for providing funding. Additionally, we would like to thank Mr. Wayne Kelly (CFSI) and Mr. Robert Otto (IBES) for their support and input.

\section{References}

Auld, G., S. Bernstein and B. Cashore. 2008. The New Corporate Social Responsibility. Ann. Rev. Env. Resour. 33(1):413-435 doi: 10.1146/annurev.environ.32.053006.141106.
Cashore, B. 2002. Legitimacy and the privatization of environmental governance: How non-state market-driven (NSMD) governance systems gain rule making authority. Governance 15(4): 503-529.

Cashore, B., G. Auld and D. Newson. 2004. Governing Through Markets: Forest Certification and the Emergence of Non-State Authority. New Haven, CT: Yale University Press.

CBPPL. 2001. (Corner Brook Pulp and Paper Limited). Corner Brook Pulp and Paper Woodlands Receives ISO 14001 Registration. Available at: http://iw.kruger.com/imports/pdf/en/communiques/ 2001/010717-cbrook-iso-14001-e.pdf.

Department of Fisheries, Forestry and Agrifoods. 2016. Environmental Management System (EMS). Available at: http://www.faa. gov.nl.ca/forestry/ems/index.html.

DNR. 2011a. (Department of Natural Resources Forestry). 2011 Island Wood Supply Analysis. Available at: http://www.nr. gov.nl.ca/nr/publications/forestry/2011_15_islandwood.pdf.

DNR. 2011b. (Department of Natural Resources Forestry). Strategic Plan 2011-2014.

DNR. 2012. (Department of Natural Resources). How We Manage Our Forest. Available at: http://www.nr.gov.nl.ca/nr/forestry/manage/manage.html.

Dillman, D. 2007. Mail and Internet Surveys: The Tailored Design Method (2nd ed). John Wiley \& Sons, Inc., Hoboken, NJ.

Eberlein B., K.W. Abbott, J. Black, E. Medinger and S. Wood. 2013. Transnational business governance interactions: Conceptualization and framework for analysis. Regul. Gov. 8(1): 1-21.

FPAC. 2012. (Forest Products Association of Canada). Certification status - Canada \& the Globe. Available at: http://www.certificationcanada.org/english/status_intentions/status.php.

Forest Stewardship Council Canada. 2013. On-Product Labels. Available at: https://ca.fsc.org/on-product-labels.215.htm.

Gulbrandsen, H. 2004. Overlapping public and private governance: Can forest certification fill the gaps in the global forest regime? Global Environ. Polit. 4(2): 75-99.

Lister, J.E. 2009. Co-regulating corporate social responsibility: Government response to forest certification in Canada, the United States and Sweden. (Doctoral Dissertation). University of British Columbia, Vancouver, BC. 375 p.

Luckert, M.K., D. Haley and G. Hoberg. 2011. Policies for Sustainably Managing Canada's Forests: Tenure, Stumpage Fees, and Forest Practices. Vancouver, BC: UBC Press. 228 p.

NRCan. 2013. (Natural Resources Canada). Certification. Available at: http://cfs.nrcan.gc.ca/pages/144

NRCan. 2016. (Natural Resources Canada). Forest Certification in Canada. Available at http://nrcan.gc.ca/forests/canada/certification/ 17474

Rametsteiner, E. 2002. The role of governments in forest certification - A normative analysis based on new institutional economics theories. Forest Policy Econ. 4: 163-173.

Saunders, K.C. and P.N. Duinker. 2002. Perceptions of barriers to certification of government forestry in Newfoundland. Forest. Chron. 78(6): 858-865.

Statistics Canada. 2013. Aboriginal Peoples in Canada: First Nations People, Métis and Inuit. National Household Survey - Analytical products, 2011. Available at: http://www12.statcan.gc.ca/ nhs-enm/2011/as-sa/index-eng.cfm.

Wood. P. 2009. Public Forests, Private Governance: The role of provincial governments in FSC certification. (Doctoral Dissertation). University of Toronto, Toronto, ON. 175 p. 